\title{
The Mediating Effect of Emotional Intelligence on Sustainability and Future Business Performance
}

\author{
Susan Tee Suan Chin ${ }^{1}$, Rosman Md Yusoff ${ }^{2}$ \\ ${ }^{1}$ Faculty of Business, Multimedia University, Melaka. Malaysia \\ 2 Universiti Tun Hussesin Onn Malaysia, Johor Darul Takzim. Malaysia
}

\begin{abstract}
The COVID-19 pandemic has engulfed numerous parts of the world, crippling economies. Many countries' government has issued lockdown orders to curb the spread of the COVID-19 virus. This lockdown has created a new norm for society. Unfortunately, businesses have been badly affected by the lockdown. Thus, business leaders needed to dig deep and think of ways to sustain their organisation and move forward. This study selected a successful manufacturing company and examined the mediating effects of emotional intelligence against two other variables, namely organisational citizenship behaviour and job satisfaction of the company's executives during the challenging situation. The questionnaires were adapted from Palmer and Stough (to determine emotional intelligence) and Podsakoff et al. (to examine organisational citizenship behaviour) and were emailed to the executives via the human resource manager. The survey was participated by 110 executives. Results revealed that emotional intelligence played a mediating role in enhancing organisational performance.
\end{abstract}

Keywords: Performance; Productivity; Environment

This is an open access article under the CC-BY-NC license

\section{INTRODUCTION}

The year 2020 has not been a typical business year, whereby some business sectors have almost gone to a total standstill due to the COVID-19 pandemic. To date, certain industries are still lagging, especially the tourism and aviation industries. Organisations need to stay resilient to sustain and steer themselves out of the turbulence (Deloitte Development LLC, 2020). The disruption faced by the organisations has put to the test their emotional and social operating system and functioning, i.e. emotional intelligence (Stokes, 2020). The COVID-19 pandemic has jolted many organisations, forcing them to shift platforms and change their strategies. One of the business strategies adopted from the Resource-Based View Model is to focus on the people to sustain. While technical skills are vital, soft skills have now gained much importance (Dean, 2017). Moreover, with the uncertainty due to the pandemic, employees' level of job satisfaction has also been tested.

The pandemic has made the business environment even more complex and complicated. As companies encounter a changing competitive field, the employee skill set needs are shifting to match this new field. The new world comprises workgroups that can interact with people from different nations and with varying cultural backgrounds. It is crucial for workers to have interpersonal communication skills to work with and comprehend their team members. The employee mixture is undergoing change. 'In some ways, business mirrors biology. As Darwin surmised, those who survive "are not the strongest or the most intelligent, but the most adaptable to change" (Stokes, 2020). This study's purpose is to examine the influence of emotional intelligence skills during the COVID-19 situation, which has proven to be very 
challenging. In addition, the study also focuses on the employees' job satisfaction level and organisational citizenship behaviour.

\section{LITERATURE REVIEW}

\section{Emotional Intelligence}

Emotional intelligence is a soft skill, which affects employees and business productivity. Soft skills are abilities or qualities that can be categorised as a personality trait or habit and include interpersonal skills such as emotional intelligence and organisational citizenship behaviour (Feffer, 2016). It has been said that soft skills, which drive the business, signify core values. Meanwhile, emotional intelligence is the ability of people to successfully handle extreme emotions that affect not only them but others around them. Extreme emotions are such as anger, sadness, fear, and happiness. Highly emotionally intelligent people are said to be highly productive and will substantially influence the organisation's performance.

It has been argued that workers with higher emotional intelligence will stay and work with the organisation during challenging situations (Hahn \& Pedersen, 2020). This is needed, especially during the current COVID-19 pandemic. According to Danquah (2014) and Hashem (2010), high emotional intelligence leads to enhanced performance. Based on the construct developed by Palmer and Stough (2001), five emotional competencies are displayed at the workplace, i.e. emotional recognition and expression, understanding others' emotions, emotions direct cognition, emotional management, and emotional control. Employees with higher emotional intelligence tend to be aware of the situations their colleagues are experiencing. These employees tend to recognise the level of emotions in their surroundings and can show their empathy and concern toward their colleagues. Such behaviour improves the working environment. Furthermore, it strengthens the bond among the employees, and this then becomes an asset to the organisation.

\section{Organisational Citizenship Behaviour}

Displaying support to the organisation and being conscientious in the workplace are examples of organisational citizenship behaviour. As listed by Podsakoff et al. (1990), it comprises five elements i.e. conscientiousness, sportsmanship, civic virtue, courtesy, and altruism. Organisational citizenship behaviour positively affects the workers and is anticipated to increase productivity (Hall et al. 2009). Moreover, Farooqui (2012) said it supports workers to function better and perform job roles effectively. These behaviours or skills are important, especially during challenging situations such as the COVID-19 pandemic. It gives the flexibility necessary to work through various unexpected circumstances, such as assisting workmates needing urgent help. Additionally, its positive inclusion is shown when workers propose enhancements in and around the company, care for the company's assets, and possess commendable attendance attitudes beyond enforceable levels (Organ, 1990).

\section{Job Satisfaction}

Hoppock (1935) has suggested that job satisfaction is any combination of psychological, physiological, or environmental conditions causing an individual to express that he is honestly content with his job. An individual's satisfaction is said to be an affective reaction and attitude to his or her job (Zaman \& Rahman, 2013). Therefore, the attitude of workers demonstrates their job satisfaction level. Lee, Lee and Lin (2014) have stated that satisfied workers are more committed to their job. These employees are more productive. Scholars like Zaman and Rahman (2013), Taboli (2013), and Sahdat and Sajjad (2011) have concurred with this claim. They have suggested that a content worker will enhance the 
organisation's performance. The year 2020 has been very turbulent. Organisations need employees who are not only satisfied but willing to go further. A worker satisfied with his employer may plan to work longer, but his productivity level is indirectly related to organisational performance (Rahman \& Hoque, 2014). Satisfied employees are only pleased with their present condition and are in their comfort zone, but they do not have intentions to work harder for the organisation.

\section{RESEARCH METHOD}

For this study, a successful manufacturing company was chosen. The company is situated in Selangor, Malaysia. Successful organisations can effectively and efficiently utilise their limited resources. The chosen manufacturing organisation has been in operation for more than 50 years. This company started with two staff and now have around 1,000 workers. Furthermore, the company has been named as one of the top 10 producers by the Malaysian Plastics Manufacturers Association. The researcher was not allowed to enter the organisation during the Recovery Movement Control Order (RMCO). Thus, the questionnaire was distributed by the company's human resource officers, and all the executives participated.

The study focused on four variables, i.e. emotional intelligence, job satisfaction, organisational citizenship behaviour, and organisational performance. The research objectives are:

1. To investigate the relationships among emotional intelligence, organisational citizenship behaviour, job satisfaction, and organisational performance.

2. To determine the mediating effect of emotional intelligence in the relationships among organisational citizenship behaviour, job satisfaction, and organisational performance.

The study used three different questionnaires. For emotional intelligence, the study used the construct of Palmer \& Stough (2001). For organisational citizenship behaviour, the study used the framework by Podsakoff et al. (1990). The study used the construct by Brayfield \& Rothe (1951) to analyse the level of job satisfaction. Data validity was tested using Cronbach's alpha.

\section{FINDINGS AND DISCUSSION}

Table 1 shows the regression analysis results of the three independent variables (emotional intelligence, organisational citizenship behaviour, and job satisfaction). It was noted that these three variables accounted for $92.2 \%$ of the variations. The high percentage indicated that these three variables had a strong influence during the challenging COVID-19 situation. Since their $p$ values were lower than 0.05 , emotional intelligence and job satisfaction were significant. Meanwhile, the p-value for organisational citizenship behaviour was more than 0.05 , hence, insignificant. Organisational performance during COVID-19 was the dependent variable.

Table 1. Regression analysis and model summary

\begin{tabular}{|c|c|c|c|c|c|}
\hline \multirow[b]{2}{*}{ Model } & \multicolumn{2}{|c|}{ Unstd Coeff } & \multirow{2}{*}{$\begin{array}{c}\text { Std Coeff } \\
\text { Beta }\end{array}$} & \multirow[b]{2}{*}{$\mathrm{t}$} & \multirow[b]{2}{*}{ Sig. } \\
\hline & $\mathrm{B}$ & SE & & & \\
\hline EI & .215 & .060 & .160 & 3.559 & .001 \\
\hline OCB & .015 & .050 & 011 & 297 & .767 \\
\hline JS & .878 & .048 & .823 & 18.206 & .000 \\
\hline $\begin{array}{l}\mathrm{R} \\
960^{\mathrm{a}}\end{array}$ & $\begin{array}{l}\text { R Squ } \\
922\end{array}$ & & $\begin{array}{l}\text { Adjusted } \\
920\end{array}$ & are & \\
\hline
\end{tabular}


Note: EI - emotional intelligence; OCB - organisational citizenship behaviour; JS-job satisfaction

Table 2 presents the analysis results of the five emotional intelligence dimensions. Four dimensions, i.e. emotional recognition and expression (ERE), emotions direct cognition (EDC), emotional management (EM), and emotional control (EC), had a significant relationship with organisational performance. Using the $t$ values as a guide, We found that ERE and EDC had a significant influence on the employees. This indicates that workers with higher emotional intelligence tend to be better at recognising and expressing their emotions. Also, they have better skills in decision making, which is an important responsibility of the executives.

Table 2. Regression analysis - Dimensions of emotional intelligence

\begin{tabular}{|c|c|c|c|c|c|}
\hline \multicolumn{6}{|l|}{ Coefficients } \\
\hline & Uns & td Coeff & Std Coeff & & \\
\hline Model & B & Std. Error & Beta & $\mathrm{t}$ & Sig. \\
\hline (Constant) & .023 & .331 & & .069 & .945 \\
\hline ERE & .320 & .070 & .325 & 4.565 & .000 \\
\hline UOE & .158 & .082 & .149 & 1.931 & .056 \\
\hline EDC & .250 & .072 & .263 & 3.477 & .001 \\
\hline EM & .164 & .076 & .168 & 2.155 & .033 \\
\hline EC & .178 & .069 & . 167 & 2.596 & .011 \\
\hline
\end{tabular}

Notes: a - Dependent variable (OP); ERE - emotional recognition and expression; UOE - understanding others' emotions; EDC - emotions direct cognition; EM - emotional management; EC - emotional control

Based on the direct effect (0.0629) and indirect effect (0.1112) values (Table 3), emotional intelligence impacted the relationships among job satisfaction, organisational citizenship behaviour, and organisational performance. This shows that for organisations to sustain during turbulent times, they need employees who are emotionally intelligent. Such employees can manage their emotions during hard times, and they will have good interpersonal skills to communicate with their colleagues. This then creates a good workplace environment.

Table 3. The indirect and direct effect of emotional intelligence on organisational performance

\begin{tabular}{llll}
\hline \multicolumn{4}{c}{ The direct effect of organisational citizenship behaviour and job satisfaction on } \\
organisational performance
\end{tabular}


For organisations to sustain themselves, they need good employees who will be a strong backbone to them. The indirect effect of emotional intelligence amplified both organisational citizenship behaviour and job satisfaction's influence. Emotionally intelligent employees can handle their emotions and comprehend the situation the organisation is in. For example, the COVID-19 pandemic has pushed the world economy to a new low, and many industries are finding it challenging to handle the situation.

The indirect effect of emotional intelligence highlights the importance of its role to manage the emotions of the employees. In the examined organisation, there were no pay cuts as they did have overseas contract orders. Nevertheless, the work-life balance has been disrupted due to the movement restriction orders. The restriction and the pandemic have made life unpredictable. This uncertainty has created anxiety and doubt among many people.

\section{CONCLUSION \& FURTHER RESEARCH}

This research, which took place during the movement restriction period, emphasised the mediating role of emotional intelligence in sustaining organisational performance. A successful company was used to investigate the importance of emotional intelligence that influenced the other variables in this study, i.e. organisational citizenship behaviour and job satisfaction. Emotional intelligence refers more to the interpersonal skills of the employees, such as communication skills and level of cooperation and collaboration. Future studies can determine the other soft skills needed in an organisation.

This research has a few limitations. The study was conducted during the pandemic, and there were movement restrictions. The present researchers were not able to have a face to face interview with the respondents. The questionnaires were distributed through the human resource personnel. The authorities did not allow the workforce to be working at full capacity. The sample size was reduced by $50 \%$. Findings might be restrictive due to the sample size. As the study was conducted during the pandemic, some of the respondents may be emotionally upset, especially if one of their family members was impacted by the effects. The study only used three independent variables; they are emotional intelligence, organisational citizenship behaviour and job satisfaction. Findings are restrictive to these variables. There could be other variables that could be analysed. The study was conducted on a single successful organisation in the plastic manufacturing industry. Hence, findings would be restrictive to organisations with a similar background.

It would be beneficial to conduct the same research in other organisations. The results of this study relate to other organisations with similar characteristics. However, each organisation may have some differences, and these differences would be added knowledge and advantage for the other organisations. There could be other variables that could be used in the study, for example, culture in the organisation.

\section{REFERENCES}

Danquah, E 2014, 'Analysis of the impact of emotional intelligence on organisational performance: A banking perspective', British Journal of Marketing Studies, vol. 6, No. 3, pp. 34-50.

Dean, SA 2017, Soft skills needed for the 21st century workforce, Doctoral dissertation, Walden University.

Deloitte Development LLC 2020, Covid-19 future of remote work, viewed September 2020, https://www2.deloitte.com/content/dam/Deloitte/mt/Documents/about-deloitte/dtmt-COVID-19future-of-remote-work.pdf

Farooqui, MR 2012, 'Measuring organisational citizenship behaviour (OCB) as a consequence of organisational climate (OC)', Asian Journal of Business Management, vol. 4, no. 3, pp. 294-302. 
Feffer, M 2016, HR's hard challenge: When employees lack soft skills, viewed 6 March 2020, https://www.shrm.org/hr-today/news/hr-magazine/0416/pages/hrs-hard-challenge-whenemployees-lack-soft-skills.aspx

Hahn, SE \& Pedersen, J 2020, 'Employers needs versus student skillsets', Practical Academic Librarianship: The International Journal of the SLA Academic Division, vol. 10, no. 1, pp. 38-53.

Hall, AT, Zinko, RP, Alexia, AF \& Gerald, R 2009, 'Organisational citizenship behaviour and reputation mediators in the relationship between accountability and job performance and satisfaction', Journal of Leadership \& Organisational Studies, vol. 15, no. 4, pp. 391-392.

Hashem, TN, 2010, 'The impact of managers' emotional intelligence on marketing creativity in Jordan Commercial Bank', Innovative Marketing, vol. 6, no. 3, pp. 78-86.

Hoppock, R 1935. Job satisfaction, Harper, New York.

Lee, YJ, Lee, IC \& Lin CL 2014, 'The effects of employees' satisfaction and leadership styles on organisational performance: Organisational commitment as a dual mediator', Asian Journal of Empirical Research, vol. 4, no. 2, pp. 104-124.

Organ, DW 1990, 'The motivational basis of organisational citizenship behaviour', in BM Shaw \& LL Cummings (eds), research in organisational behaviour, JAI Press, Greenwich CT.

Palmer, B \& Stough, C 2001, Swinburne University emotional intelligence test interim technical manual, Swinburne University, Melbourne.

Podsakoff, PM, MacKenzie, SB, Moorman, RH \& Fetter, R 1990, 'Transformational leader behaviors and their effects on followers' trust in leader, satisfaction, and organisational citizenship behaviors', The Leadership Quarterly, vol. 1, no. 2, pp. 107-142.

Rahman, MM \& Hoque, MM 2014, 'An analysis of job satisfaction: A study on United Commercial Bank Limited', International Journal of Ethics in Social Sciences, vol. 2, no. 2, pp. 117-131.

Sahdat, M \& Sajjad, SI 2011, 'Emotional intelligence and organisational productivity: A conceptual study', World Applied Sciences Journal, vol. 15, no. 6, pp. 821-825.

Stokes, C 2020, TechTank: Workplace emotional intelligence during the global coronavirus outbreak, viewed 2020, https://www.brookings.edu/blog/techtank/2020/03/11/workplace-emotional-intelligence-duringthe-global-coronavirus-outbreak/

Taboli, H 2013, 'Job satisfaction as a mediator in relationship between emotional intelligence, organisational commitment in employees' Kerman Universities', Life Science Journal, vol. 10, no. 1, pp. 18.

Zaman, FB \& Rahman, MS 2013, 'Job satisfaction of women in the corporate world', Interdisciplinary Journal of Contemporary Research in Business, vol. 5, no. 8, pp. 9-22. 
Journal of Governance Risk Management Compliance and Sustainability (JGRCS), Vol. 1 (1), 01-06 The Mediating Effect of Emotional Intelligence on Sustainability and Future Business Performance Susan Tee Suan Chin, Rosman Md Yusoff 